\title{
IMPLEMENTASI PENGHARGAAN DAN KONSEKUENSI BERDASARKAN PENDIDIKAN KRISTEN DI KELAS 4C SEKOLAH DASAR KRISTEN "H” MALANG
}

\author{
Emmanuela Oktafiyeni Baik \\ Program Studi Pendidikan Guru Sekolah Dasar, \\ Universitas Kristen Petra \\ Jl. Siwalankerto 121-131, Surabaya \\ E-mail: emmanuelao59@gmail.com
}

\begin{abstract}
ABSTRAK
Penelitian ini dilakukan untuk mengetahui pengimplementasian penghargaan dan konsekuensi berdasarkan pendidikan Kristen sebagai metode mendisiplinkan murid. Sekolah Dasar Kristen " $H$ " Malang sebagai salah satu sekolah yang menggunakan metode ini dalam mendidik murid-muridnya. Kesesuaian perspektif guru dengan perspektif Alkitab turut menentukan pengimplementasian penghargaan dan konsekuensi ini. Teknik analisa yang digunakan dalam penelitian ini adalah deskriptif sesuai dengan teori Moleong dan Ferdiansyah. Hasil penelitian menunjukkan dalam mengimplementasikan penghargaan dan konsekuensi perlu adanya kerjasama guru sebagai wakil sekolah dengan orang tua. Pengimplementasian penghargaan dan konsekuensi perlu di lakukan di sekolah dan rumah
\end{abstract}

Kata kunci: Alkitabiah, konsekuensi, pendidikan Kristen, penghargaan, disiplin murid.

\begin{abstract}
This research is conducted to determine the implementation of rewards and consequences based on Christian education as a method of disciplining students. Malang " $H^{\prime \prime}$ Christian Elementary School is one of the schools in Malang that uses this method in educating its students. The suitability of the teacher's perspective with the Bible's perspective determines the implementation of these rewards and consequences. The analysis technique used in this research is descriptive according to the theory of Moleong and Ferdiansyah. The results showed in implementing the awards and consequences of the need for teacher cooperation as a representative of the school with parents. Implementing rewards and consequences needs to be done at school and home.
\end{abstract}

Keywords: Biblical, Christian education, consequences, rewards, student discipline.

\section{PENDAHULUAN}

Kepemimpinan Kristen adalah Pekerjaan sebagai seorang guru bukan hal yang mudah. Selain mengajar dan membimbing, guru juga memiliki tugas lain yaitu mendisiplinkan murid. Ada 2 hal yang dapat dilakukan oleh guru untuk mendidik murid yaitu pendekatan disiplin dan pendekatan konseling. Pendekatan disiplin ini merujuk pada aturan sekolah serta sanksi yang berlaku. Pada penelitian ini, peneliti akan mencari informasi mengenai bagaimana pengimplementasian penghargaan dan konsekuensi yang merupakan pendekatan disiplin. Penerapan penghargaan dan konsekuensi yang tidak tepat membuat murid merasa dirinya tidak dihargai (Suteja. J, n.d).

Pada 29 Januari 2020, Tribun menyampaikan informasi kekerasan yang dilakukan guru di daerah Sukabumi, Jawa Barat. Salah satu guru honorer memukul murid SD dengan buku LKS karena saat murid-murid ditinggal sebentar, mereka bermain-main tanpa menyelesaikan tugas mereka.

Kasus lainnya dilaporkan Tribun pada tanggal 30 April 2019, yaitu guru di salah satu sekolah swasta di Jakarta Selatan menarik telinga murid hingga memar karena tidak membawa perlengkapan seni. Dua kasus ini membuat murid mengalami luka batin dan trauma. Jadi bisa disimpulkan konsekuensi dalam bentuk kekerasan fisik dan verbal tidak memberikan dampak positif pada murid maupun guru.

Dalam menerapkan penghargaan dan konsekuensi, guru perlu memperhatikan dasar pendidikan Kristiani. Pendidikan Kristiani adalah pengajaran yang sangat efektif (Santoso, 2005). Pendisiplinan Kristen berfokus pada pembiasaan tingkah laku yang baik dan benar. Pembiasaan ini 
dilakukan atas kesadaran murid bukan karena takut pada hukuman atau konsekuensi yang akan diterima.

Tuhan

Yesus

Kristus mencontohkan penerapan kedisiplinan dalam mengajar. Ia menerapkan penghargaan dan konsekuensi pada setiap ajarannya. Setiap penghargaan dan konsekuensi yang diterima manusia, sesuai dengan apa yang dilakukannya (Efesus 6:19).

Penjelasan di atas merupakan standar peneliti untuk mencari tempat penelitian. Peneliti juga mempertimbangkan akses yang mudah untuk mencari tempat penelitian sehingga peneliti memilih Sekolah Dasar Kristen " $\mathrm{H}$ " Malang sebagai tempat penelitian. Sekolah Dasar Kristen " $H$ " adalah nama samaran yang ditentukan. Sekolah Dasar Kristen " $H$ " menjadi pilihan peneliti karena salah satu sekolah Kristen yang sangat fokus dalam mendidik murid berlandaskan pendidikan Kristiani. Mereka juga mengimplementasikan penghargaan dan konsekuensi dalam mendidik murid. Penghargaan dan konsekuensi yang diimplementasikan tidak pernah mengacu pada kekerasan fisik dan verbal. Penelitian ini akan dilakukan di kelas 4C karena memiliki murid paling banyak di antara kelas 4A dan 4B. Selain itu kelas 4C juga memiliki murid-murid yang unik sehingga membutuhkan pendisiplinan lebih. Alasan terakhir karena di awal tahun pembelajaran kelas 4C tidak memiliki guru yang selalu berada di kelas. Berdasarkan hal ini penelitian dilakukan untuk menemukan fakta-fakta implementasi penghargaan dan konsekuensi berdasarkan Pendidikan Kristen yang membawa perubahan perilaku murid di Kelas 4C Sekolah Dasar Kristen "H".

Penelitian ini bertujuan untuk menjawab pertanyaan, yaitu bagaimana penghargaan berdasarkan pendidikan Kristen diimplementasikan di kelas 4C SDK ' $H$ ' Malang, serta bagaimana konsekuensi berdasarkan pendidikan Kristen diimplementasikan di kelas 4C SDK ' $\mathrm{H}$ ' Malang.

\section{LANDASAN TEORI}

\section{Penghargaan}

Penghargaan adalah respon terhadap suatu tingkah laku yang baik sehingga meningkatkan kemungkinan pengulangan tingkah laku tersebut (Soegito, 2009). Sedangkan menurut Arikunto, penghargaan adalah sesuatu yang diberikan kepada orang lain karena sudah bertingkah laku sesuai dengan peraturan sekolah. Menurut Skinner, tingkah laku yang diinginkan dapat digambarkan dan dibentuk secara nyata melalui pemberian reinforcement yang sesuai (Suli, 2019).

Maria J. Wantah mengemukakan fungsi dari pemberian penghargaan adalah sebagai berikut: Pertama, penghargaan mempunyai nilai mendidik. Kedua, penghargaan berfungsi sebagai alat motivasi murid. Ketiga, penghargaan berfungsi memperkuat perilaku murid (Gultom \& Siahaan, 2017).

Pemberian penghargaan dalam bentuk materi berupa benda-benda yang menyenangkan dan berguna bagi murid (pensil, buku tulis, penggaris dan lain-lain.) Sedangkan non-materi berupa kata-kata yang menggembirakan (pujian), ekspesi wajah, gesture tubuh, dan sentuhan (Daningsih 2019). Gultom \& Siahaan (2017) menambahkan contoh lain yaitu penobatan/predikat serta pemberian kekuasaan, misalnya menjadi ketua kelas.

Menurut Suharsimi Arikunto (1990), hal yang harus diperhatikan dalam memberikan penghargaan yaitu: a) Penghargaan disesuaikan dengan keadaan dan sifat dari aspek yang menunjukkan keistimewaan prestasi; b) Penghargaan harus diberikan kepada murid setelah melakukan perilaku yang dikehendaki; c) Penghargaan harus berhubungan dengan prestasi; d) Penghargaan harus bervariasi; e) Penghargaan harus bersifat pribadi; f) Penghargaan sosial harus segera diberikan; g) Penghargaan hendaknya disertai penjelasan rinci tentang alasan dan sebab mengapa murid menerima penghargaan tersebut (Prima, 2016. Gultom \& Siahaan, 2017).

\section{Konsekuensi}

Konsekuensi merupakan alat pendidikan yang bersifat negatif dan tidak menyenangkan. Konsekuensi dapat menjadi alat pendorong untuk memotivasi murid dalam berkembang (Prima, 2016). Menurut Musnarsiah (2018), pengertian hukuman atau konsekuensi adalah dampak yang harus diterima murid karena melakukan kesalahan, supaya murid tidak lagi melakukannya. Menurut Purwanto maksud dari konsekuensi adalah penguatan negatif yang diberikan dengan sengaja oleh orang tua atau guru (dalam Daningsih, 2019). Menurut Miranda (2018), konsekuensi juga salah satu alat dalam mendisiplinkan murid.

Menurut Amir Daien, syarat-syarat pemberian konsekuensi dalam pendidikan adalah: a) Pemberian konsekuensi harus tetap dalam jalinan cinta kasih sayang; b) Pemberian konsekuensi harus didasarkan pada alasan yang tepat; c) Pemberian konsekuensi harus menimbulkan kesan pada hati murid; d) Pemberian konsekuensi harus diikuti dengan konfirmasi antara guru dengan murid (Wilujeng, 2015).

William Stern membedakan tiga macam konsekuensi disesuaikan dengan tingkat perkembangan murid yaitu, konsekuensi asosiatif, konsekuensi logis, konsekuensi normatif (Miranda, 2018). Hal-hal yang perlu dipertimbangkan saat menentukan konsekuensi menurut Indrakusuma (1973) yaitu: pertama, ringan 
dan beratnya pelanggaran. Kedua, hukuman diberikan dengan melihat jenis kelamin, usia dan karakteristik murid. Ketiga, akibatakibat yang mungkin timbul dalam konsekuensi. Keempat, konsekuensi yang diberikan yang bersifat mendidik dan berhubungan dengan kesalahan yang murid lakukan. Kelima, memberikan penjelasan kesalahan yang dilakukan murid. Keenam, tidak menggunakan hukuman fisik (Gultom \& Siahaan, 2017)

\section{Pendidikan Kristen}

Dalam pendidikan Kristen hal yang menjadi tanggungjawab guru adalah menanamkan 2 prinsip dalam hidup murid. Yang pertama adalah bahwa sesungguhnya hidup itu karunia Allah. Yang kedua adalah setiap orang memiliki tujuan hidup yang berada dalam rencana Allah. Jadi tujuan dari guru Kristen adalah pertama, membimbing murid-murid untuk menerima Tuhan Yesus sebagai Allah dan Juruselamat, lau membimbing murid untuk mengerti tujuan hidup mereka adalah untuk menggenapi rencana Allah. Dengan demikian, misi pendidikan Kristen adalah untuk pemuridan dan menyelenggarakan proses pendidikan yang menolong murid membangun dasar yang benar dan bisa berdiri teguh di tengah zaman modern (Santoso, 2005).

Misi pendidikan Kristen ini secara langsung menyatakan bahwa sekolah memiliki tanggung jawab untuk membentuk karakter murid. Sehingga murid memiliki hidup yang taat dan sesuai dengan Firman Allah. Menurut Brummelen (Puspitasari, 2016), pendidikan Kristen berperan untuk membantu dan membimbing murid menjadi seorang Kristen yang takut akan Tuhan, yang menyadari bahwa hidupnya yang dikuasai dosa telah bersih ditebus oleh Kristus melalui pengorbanannya di atas kayu salib. Hal ini mendorong murid untuk mempertanggungjawabkan hidupnya yang sudah diselamatkan kepada Kristus dengan cara taat kepada perintah Allah. Mereka juga harus menyadari bahwa setiap perbuatan yang mereka lakukan akan mendapatkan penghargaan dan konsekuensi.

Konsep penghargaan dan konsekuensi yang Tuhan pernah nyatakan dalam ajaran Alkitab salah satunya adalah perumpamaan tentang talenta (lihat Matius 25:14-30). Manusia akan mendapatkan penghargaan saat ia melaksanakan tanggung jawabnya. Konsekuensi diberikan saat tanggung jawab itu tidak dijalankan.

\section{METODE PENELITIAN}

\subsection{Desain Penelitian}

Jenis penelitian adalah penelitian kualitatif karena menggunakan deskriptif analitik, data disusun dan dijelaskan menggunakan kata-kata dan gambar, serta analisis data berupa pemaparan hasil pengamatan pada subjek dan respon yang diberikan murid dalam bentuk uraian naratif (lihat Moleong, 2009). Penelitian dilakukan di Sekolah Dasar Kristen (SDK) "H” Malang.

\subsection{Subjek Penelitian}

Subjek penelitian ini adalah Bu Ika (nama samaran) yang bekerja selama kurang lebih 5 tahun sebagai pengajar di SDK " $\mathrm{H}$ ". Bu Ika adalah informan kunci, yaitu wali kelas $4 \mathrm{C}$ yang memiliki 13 murid laki-laki dan 11 murid perempuan. Dari 24 murid di kelas 4C, 2 murid berasal dari keluarga sederhana dan sisanya berasal dari keluarga berpenghasilan lebih. Alasan pemilihan subjek penelitian adalah karena Bu Ika mampu memberi informasi terkait dengan penelitian yang sedang dilaksanakan (lihat Arikunto, 1989).

\subsection{Metode dan Prosedur Pengambilan Data 3.3.1. Observasi}

Observasi yang dilakukan adalah jenis observasi partisipan, karena peneliti terlibat langsung dengan kegiatan sehari-hari orang yang sedang diamati. Hal ini berarti peneliti ikut membantu hal-hal yang dikerjakan oleh subjek atau sumber data. Selain itu peneliti juga mencatat hal-hal yang ditemukan, seperti data tentang situasi dan kondisi secara luas dari tempat penelitian hal ini mencakup letak lokasi sekolah, kurikulum, kondisi sarana dan prasarana yang ada di SDK "H”.

\subsubsection{Wawancara}

Wawancara yang digunakan dalam penelitian ini adalah wawancara terstruktur dan tidak terstruktur (lihat Bungin dalam Lukman, n.d). Wawancara tidak struktur dilakukan ketika ditemukan suatu hal yang unik saat melakukan observasi dan langsung bertanya pada subjek. Sedangkan wawancara terstruktur dilakukan untuk mendapatkan data pendukung dari guru-guru lainnya. Pertanyaan yang diajukan untuk mencari data mengenai implementasi penghargaan dan konsekuensi berdasarkan pendidikan Kristen terhadap perubahan perilaku murid di SDK " $H$ " Malang.

\subsubsection{Dokumentasi}

Dalam penelitian ini metode dokumen berupa catatan-catatan, buku, jurnal, internet, foto, dan dokumen lainnya yang berhubungan dengan implementasi penghargaan dan konsekuensi berdasarkan pendidikan Kristen terhadap perubahan perilaku murid di SDK " $H$ " Malang untuk mendukung penelitian (lihat Ibid dalam Lukman, n.d.)

\subsection{Teknik Analisis Data}

Tahap analisa data yang dilakukan adalah sebagai berikut (lihat Ferdiansyah, 2015. Suprayogo dalam Lukman, n.d) : 
1. Tahap reduksi data. Pada tahap ini, peneliti merangkum data yang diperoleh melalui observasi, wawancara, dan dokumentasi. Kemudian menggolongkan berdasarkan variabel penelitian. Setelah itu memfokuskan data yang berasal dari lapangan dan mencari pola untuk memberikan gambaran yang lebih tajam tentang hasil pengamatan.

2. Tahap display data. Pada tahap ini, peneliti menampilkan hasil reduksi melalui teks naratif. Hasil pengumpulan data melalui metode observasi, wawancara dan dokumen dijelaskan dalam kata-kata dan kalimat naratif.

3. Tahap verifikasi data. Pada tahap ini peneliti menyimpulkan data yang telah ditunjukkan melalui teks naratif setelah melakukan verifikasi pada data hasil penelitian.

\subsection{Uji Validitas dan Reliabilitas}

Untuk menguji validitas penelitian, peneliti menggunakan teknik triangulasi yang memeriksa keabsahan data dengan memanfaatkan data lainnya sebagai pembanding. Peneliti membandingkan data hasil pengamatan dengan data hasil wawancara. Peneliti juga membandingkan data hasil pengamatan dengan teori-teori yang berkaitan (lihat Moleong, 2009). Selain itu, peneliti melibatkan diri membantu guru mengajar pelajaran Matematika di kelas 4C selama kurang lebih 3 bulan agar dapat membantu menggambarkan dengan tepat pengalaman hidup subyek dalam mengimplementasikan penghargaan dan konsekuensi sehingga tingkat validitas semakin tinggi (lihat Hall dan Stevens dalam Afiyanti, 2006).

Peneliti menggunakan 2 dari 3 tes, yaitu tes stabilitas dan tes konsistensi sebagai uji reliabilitas (lihar Afiyanti, 2006). Pertama, tes stabilitas. Jawaban dari sumber-sumber pendukung dibandingkan dan dilihat kesamaannya dalam memberikan jawaban. Kedua, tes konsistensi dengan membandingkan hasil wawancara dengan observasi yang dilakukan peneliti dapat menghasilkan data yang sama.

\section{ANALISA DATA \\ 4.1 Implementasi Penghargaan Berdasarkan Pendidikan Kristen di Kelas 4C SDK "H" Malang.}

Sekolah Dasar Kristen "H" mengimplementasikan penghargaan dalam mendidik murid-muridnya. Penghargaan yang diberikan tidak harus berbentuk barang, bisa berbentuk pujian, perhatian sentuhan dan lain-lain (lihat Purwanto dalam
Daningsih,2019). Ada berbagai macam bentuk penghargaan yang diimplementasikan di Kelas 4C SDK "H" yaitu personal point, class point, free assignment, extra recess, special privilege, student of the month dan verbal praise.

Bentuk penghargaan pertama adalah personal point. $\mathrm{Bu}$ Ika memberikan penghargaan personal point untuk mengapresiasi setiap murid dalam melakukan sesuatu sesuai dengan karakteristik setiap murid. Poin - poin yang dikumpulkan ditukarkan dengan tiket-tiket penghargaan. Penghargaanpenghargaan itu adalah free stationary, free assignment, extra recess, penghargaan from parents, plus 10 class poin berdasarkan hasil kesepakatan diskusi antara guru satu level, dan juga murid.

Bentuk penghargaan kedua adalah class point. Tujuan pemberian penghargaan ini untuk mengajarkan pentingnya kerjasama. Saat kelas poin mencapai target yang telah disepakati guru dan murid akan mengadakan pesta kelas. Pesta kelas ini bisa berupa berenang bersama, nonton film di kelas, makan-makan dan lain sebagainya. Bentuk penghargaan ketiga adalah free assignment. Tiket ini hanya berlaku satu kali pada tugas devotion day book. Devotion day book adalah buku yang berisi tugas renungan murid-murid. Tugas ini diberikan satu minggu 2 kali. Penghargaan ini membuat murid sangat senang karena mereka tidak perlu mengerjakan tugas tersebut.

Bentuk penghargaan ketiga adalah special privilege dengan memberikan kesempatan kepada murid menjadi seorang tutor bagi teman sebayanya. Hak istimewa menjadi tutor sebaya yang diterima murid adalah bentuk dari guru menghargai kemampuannya. Hal ini sesuai dengan 1 Timotius 4:12 yang menyatakan "Jangan seorangpun menganggap engkau rendah karena engkau muda. Jadilah teladan bagi orang-orang percaya, dalam perkataanmu, dalam tingkah lakumu, dalam kasihmu, dalam kesetiaanmu dalam kesucianmu".

Bentuk penghargaan kelima adalah student of the month. Saat murid mendapatkan gelar Student Of The Month foto mereka akan dipajang di bingkai selama 1 bulan. Penghargaan ini tidak hanya melihat sisi akademik murid, tetapi melihat karakter murid berdasarkan nilai sekolah.

Bentuk penghargaan keenam adalah verbal praise. Pujian diterima murid saat mereka berhasil mencapai sesuatu. Ada begitu banyak pujian diungkapkan oleh guru-guru seperti "Wah hebat, sudah selesai tugasnya”, "Terima kasih sudah mengumpulkan tugas tepat waktu ya nak" (tabel observasi, 2019).

\subsection{Implementasi Konsekuensi Berdasarkan Pendidikan Kristen Di Kelas 4C SDK "H" Malang.}

Selain penghargaan SDK " $H$ " juga mengimplementasikan konsekuensi dalam mendidik murid-muridnya. Konsekuensi yang diimplementasikan memiliki level atau tahapan. 
Tahap pertama yang dilakukan adalah peringatan sebanyak 3 kali. Jika tidak ada perubahan dalam sikap murid maka dibawa ke ruang LAC (Learning Assistance Center) untuk bercerita mengenai masalah yang terjadi. Jika sampai titik ini tidak ada perubahan, orang tua akan dipanggil dan membuat perjanjian. Konsekuensi terakhir adalah murid dikeluarkan dari sekolah. Tahap-tahap ini bisa berubah dan melompat, jika ada kondisi dimana kesalahan yang dilakukan murid fatal, misalnya merundung murid lain sampai ketakutan, mencuri, memukuli teman dan sebagainya (lihat Indrakusuma, 1997).

Ada berbagai macam bentuk konsekuensi yang diimplementasikan di Kelas 4C SDK "H" yaitu verbal warning, time out, you break it - you fix it, logical consequences, loss of a privilege, detention, loss personal point dan loss class point.

Bentuk konsekuensi yang pertama adalah verbal warning. Peringatan dengan kata-kata adalah konsekuensi dengan tahapan paling rendah. Konsekuensi ini paling sering diimplementasikan guru saat kegiatan belajar mengajar berlangsung. Peringatan biasanya dilakukan maksimal sebanyak 3 kali. Namun, tidak jarang hanya dilakukan 1 kali saja. Bentuk konsekuensi yang kedua adalah time out. Time out terjadi jika muridmurid tidak menyadari kesalahan meskipun sudah mendapatkan teguran. Tujuan pemberian konsekuensi ini adalah murid diberikan waktu untuk merenungi kesalahan mereka.

Bentuk konsekuensi yang ketiga adalah you break it - you fix it. Saat murid menumpahkan minuman atau kotoran mesin rautan. Guru akan meminta murid itu membersihkan kotoran itu sendiri. Konsekuensi ini mengajarkan murid untuk bertanggung jawab pada tindakan berdampak buruk yang tidak sengaja mereka lakukan. Bentuk konsekuensi yang keempat adalah logical consequences. Misalnya saat murid tidak mengerjakan tugas, guru meminta murid untuk menyelesaikan tugasnya hari itu juga. Murid mendapatkan waktu di jam recess, play time dan pulang sekolah untuk menyelesaikan tugas itu.

Bentuk konsekuensi yang kelima adalah loss of a privilege. Konsekuensi ini diberikan saat tindakan buruk murid membuat orang dan atau diri sendiri cedera dan mengalami kerugian. Saat sekelompok murid bermain bersama dan menyebabkan kecelakaan yang membuat beberapa murid mengalami cedera. Maka hak murid-murid tersebut untuk bermain akan dihilangkan sementara. Jika murid-murid tersebut bisa mengontrol diri mereka selama waktu yang disepakati sebelumnya. Maka hak mereka untuk bermain di luar kelas akan dikembalikan tapi tetap dengan tanggung jawab. Bentuk konsekuensi yang keenam adalah detention. Penahanan atau ditahan adalah tindakan lanjutan jika konsekuensi level menghilangkan hak murid tidak membuat dia berubah. Murid murid melakukan kegiatan belajar, recess, playtime di ruangan yang terpisah dengan teman-teman lainnya. Ruangan-ruangan itu adalah LAC (Learning Assistance Center), ruang koordinator dan ruang kepala sekolah.

Bentuk konsekuensi yang ketujuh adalah loss personal point dan loss class point. Pengurangan poin kelas dan poin individu adalah konsekuensi yang sering diimplementasikan di kelas. Namun, konsekuensi ini tidak tertulis. Peneliti menanyakan hal ini kepada guru kelas. Beliau menjelaskan bahwa pengurangan poin kelas dan poin individu bukan hal baru lagi. Murid tahu bahwa saat melakukan pelanggaran, akan mendapatkan pengurangan poin kelas atau poin individu.

\subsection{Perspektif Alkitab}

SDK "H" memilih metode penghargaan dan konsekuensi sebagai salah satu cara mendidik dan mengapresiasi murid-murid dalam melakukan sesuatu yang lebih dari pada biasanya sehingga terbentuk kebiasaan yang baik.

Peneliti melihat ini sebagai konsep anugerah atau kasih karunia. Dimana tidak ada rumus pasti jika murid melakukan A akan mendapatkan penghargaan A. Semua disesuaikan dengan karakteristik setiap murid. Layaknya gembala, guru Kristen yang benar tahu kebutuhan setiap muridnya satu persatu. Konsep ini sesuai dengan perumpamaan talenta dalam Matius 25:14-15 (lihat Alkitab).

Pemberian penghargaan dan konsekuensi diberikan untuk mendidik murid memiliki perilaku yang disetujui masyarakat serta sebagai petunjuk bagi murid untuk tahu mana yang boleh dan tidak dilakukan.

Penghargaan dan konsekuensi mengajarkan kepada murid tentang kehidupan. Bahwa manusia memiliki hak untuk memilih. Namun, ada harga yang harus dibayar dalam setiap pilihan yang diambil. Hal ini diajarkan dengan tujuan menyiapkan murid untuk kehidupan yang nyata

\subsection{Saran}

Beberapa saran yang dapat peneliti berikan adalah sebagai berikut :

1. Saran akademis, penelitian ini bisa dilakukan pada sekolah yang memiliki murid dengan tingkat ekonomi menengah kebawah, serta topik penelitian serupa dapat dilakukan lebih spesifik dan detail. Dengan cara mengambil salah satu penghargaan dan/atau konsekuensi yang ada. Sehingga hasil penelitian yang diberikan lebih fokus dan jelas. 
2. Saran praktis, diharapkan implementasi penghargaan dan konsekuensi berdasarkan pendidikan Kristen dapat dikaji ulang. Ada beberapa penghargaan yang tidak efektif dalam pelaksanaannya. Misalnya penghargaan lunch with two friends bisa diganti dengan memilih biskuit, kue dan makanan lainnya yang disediakan guru. Sehingga tidak menyalahi syarat-syarat pemberian penghargaan.

\section{DAFTAR REFERENSI}

Agustina, N. (2012). Penerapan penghargaan dan konsekuensi sebagai upaya meningkatkan hasil belajar murid kelas V mata pelajaran Matematika SDN 03 Nglebak Kecamatan Tawangmangu. Unpublished undergraduate thesis. Universitas Muhammadiyah Surakarta. Surakarta. Retriever from http://eprints.ums.ac.id/17058/1/Judul_Skri psix.pdf.

Alkitab. (2019). Jakarta, Indonesia: Lembaga Alkitab Indonesia.

Arikunto, S. 1989. Prosedur Penelitian. Jakarta: Bina Aksara.

Daningsih. (2019). Berartinya reward bagi anak didik. Radar Kudus. Retrieved from https://radarkudus.jawapos.com/read/2019/1 1/08/165079/berartinya-reward-bagi-anakdidik

Gultom, L., \& Siahaan, M. F. (2017). Penerapan reward dan konsekuensi untuk meningkatkan kedisiplinan murid kelas II SD Sekolah Kristen ABC. Polyglot: Jurnal Ilmiah, 12(2), 100-116. https://doi.org/10.19166/pji.v12i2.368

Kurniawan, E. (2020). Kekerasan di lingkungan sekolah, oknum guru honorer pukul siswa SD dengan buku LKS. Tribunnews.Com. Retrieved from https://www.tribunnews.com/regional/2020/ 01/29/kekerasan-di-lingkungan-sekolahoknum-guru-honorer-pukul-siswa-sddengan-buku-lks?page $=$ all

Indrakusuma, A.D. (1973). Pengantar ilmu pendidikan : Sebuah tinjauan teoritis filosofis. Malang: Fakultas Ilmu Pendidikan IKIP Malang

Manafe, I.N. (2019). Diduga Lakukan Kekerasan di Sekolah, Guru SD Dilaporkan Orangtua Murid. Retrieved from https://www.tribunnews.com/metropolitan/2 019/04/30/diduga-lakukan-kekerasan-disekolah-guru-sd-dilaporkan-orangtuamurid.

Malau, B. S. L. (2019). Diduga lakukan kekerasan di sekolah, Guru SD dilaporkan orangtua murid. Tribunnews.Com. Retrieved from https://www.tribunnews.com/metropolitan/2 019/04/30/diduga-lakukan-kekerasan-di-sekolahguru-sd-dilaporkan-orangtua-murid?page=all

Miranda, D. dkk. (2018). Penerapan Perilaku Disiplin Pada Anak Kelompok A di TK Kristen Immanuel Pontianak. Retrieved from http://jurnal.untan.ac.id/index.php/jpdpb/artic le/view/27684

Moleong, L. J. (2009). Metodologi Penelitian Kualitatif. Bandung: PT. Remadja Rosdakarya

Musnarsiah. (2018). Bentuk penghargaan yang diberikan guru kepada murid dalam pembelajaran di Sekolah Dasar 34/I Teratai. Retrieved from https://www.academia.edu/37921181/BENT UK PENGHARGAAN YANG DIBERIKA N_GURU_KEPADA_MURID_DALAM PE MBELAJARAN_DI_SEKOLAH_DASAR 3 4 I TERATAI

Nasrudin, F. (2015). Pengaruh pemberian penghargaan dan konsekuensi terhadap motivasi belajar murid kelas VI SD Negeri di Sekolah Binaan 02 Kecamatan Bumiayu Kabupaten Brebes. Unpublished undergraduate thesis. Fakultas Ilmu Pendidikan. Universitas Negeri Semarang. Semarang Retrieved from https://lib.unnes.ac.id/20269/1/1401411296s.pdf.

Purwanto, N. (2006). Psikologi pendidikan. Bandung: PT Remaja Rosdakarya.

Puspitawati. (2016). Pengantar Interaksi Belajar Mengajar yang Efektif. Jakarta: BPK Gunung Mulia.

Rahmawati, I.D. (2019). Implementasi penghargaan dan konsekuensi menumbuhkan motivasi belajar murid kelas IV SD Negeri Wonorejo 1 tahun pelajaran 2018/2019. Unpublished undergraduate thesis. Universitas Muhammadiyah Surakarta. Surakarta Retrieved from http://eprints.ums.ac.id/75021/2/artikel\%20 publikasi.pdf.

Santoso, M.P. (2005). Karakteristik Pendidikan Kristen. Retrieved from http://repository.seabs.ac.id:8080/xmlui/bits tream/handle/123456789/121/Magdalena\% 20Pranata\%20Santoso\%20\%20Karakteristik\%20Pendidikan\%20Krist en.pdf?sequence $=1 \&$ isAllowed $=y$.

Santoso, M. P. (2005). Karakteristik Pendidikan Kristen. Veritas: Jurnal Teologi dan Pelayanan, 6(2), 291-306. https://doi.org/10.36421/veritas.v6i2.153

Suli, S. dkk. (2019). Peranan Konsep Teori Behavioristik B. F. Skinner terhadap Motivasi dalam Menghadiri Persekutuan Ibadah. Retrieved from file://C:/Users/user/Downloads/Peranan\%20 Konsep\%20Teori\%20Behavioristik\%20B.\%2 
Aletheia Christian Educators Journal, Vol. 2, No. 2, Oktober 2021, 144-150

0F.\%20Skinner\%20terhadap\%20Mo

tivasi $\% 20$ dalam $\% 20 \mathrm{Menghadiri} \% 20$

Persekutuan\%20Ibadah.pdf. 